\title{
Characterization and mechanical properties of the Eocene Buda Marl
}

\author{
Péter Görög \\ D epartment of Construction $M$ aterials \\ and Engineering Geology, Budapest U niversity of Technology and Economics
}

\begin{abstract}
The mechanical behavior of the Buda Marl lies between those of rock and soil; it is therefore appropriate to define it as both weak rock and strong soil: some marl types behave like a weak rock and others like soil. In such cases the strength parameters of the material can be determined by rock mechanical or soil mechanical laboratory investigations. Often a problem occurs when the material cannot be assigned to either of these classes, in which case neither the commonly-used rock mechanical nor the soil mechanical tools are applicable to define the strength properties of the material. In this case the mechanical parameters of the material can only be estimated in an empirical fashion. The goal of this paper is to demonstrate the rock mechanical properties of the marl, using an empirical method, which can be use to determine the physical properties of a material that is neither rock nor soil.
\end{abstract}

Keywords: intact rock, rock mass, geologic strength index, correlation, compressive strength, deformation modulus

\section{Types of marl}

It is well known that the marl occupies an intermediate position between clastic and chemical sedimentary rocks. Its constituents are lime and clay. Based on the percentage ratio of these constituents marl is subdivided (Table 1), not only by its name but by the different properties as well.

Calcareous marl (Fig. 1) is usually a medium strong to strong rock; therefore rock-mechanical methods can be used to investigate it. Marl proper (Fig. 2) is rather weak, but often it is laminated and easily splits along the lamination.

Address: P. Görög: H-1117 Budapest, Stoczek u. 2, Hungary

Received: June 11, 2007; accepted: September 21, 2007 
Table 1

Groups of marl according to lime and clay content (Bárdossy 195x)

\begin{tabular}{|c|c|c|}
\hline $\mathrm{CaCO}_{3}[\%]$ & Clay [\%] & Name of the rock \\
\hline $80-60$ & $20-40$ & Calcareous marl \\
\hline $60-40$ & $40-60$ & Marl \\
\hline $40-20$ & $60-80$ & Clay marl \\
\hline
\end{tabular}

Because of its laminated construction it is almost impossible to obtain samples of marl, so its rock-mechanical investigation is hardly possible. Soil mechanical investigations are not easy to carry out either, because it is usually harder than an undisturbed specimen could provide. Plastic limit or grain-

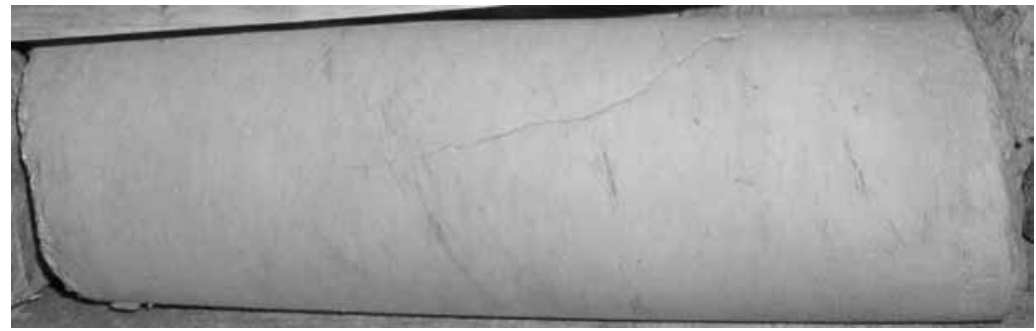

Fig. 1

Calcareous marl

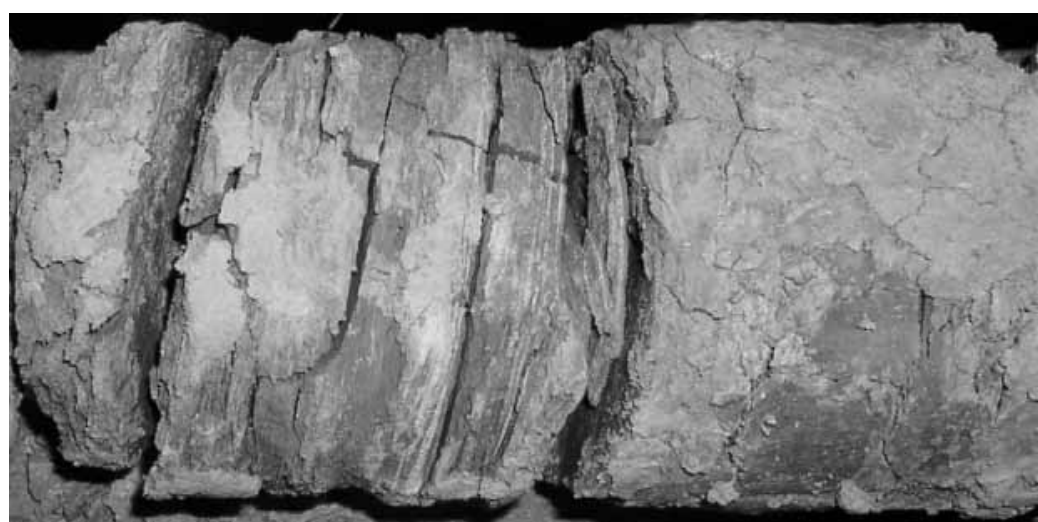

Fig. 2

Marl

size distribution, if they can be defined, do not provide enough information on its physical properties. Clay marl (Fig. 3) and highly weathered marl largely behave like clay, but often exhibit laminated structure. Soil-mechanical methods are most useful to investigate them.

There is no sharp limit between the three types of marl. The correct investigation method can be defined by macroscopic observation of the rock samples or in situ investigation. One such example is presented in Fig. 4.

In most cases, highly weathered marl and clayey marl possess plastic properties (Fig. 5); in order to investigate them, soil-mechanical methods are useful. Their plasticity index can easily be determined and an intact sample can undergo shear strength tests. Statistical analyses of the physical parameters of the Oligocene and Eocene clays of Buda were made by T. Paál (Paál 1974, 1975, 1976); this paper focuses on the other two types of marl and does not contain the results of the previous investigations. 
Fig. 3

Clayey marl

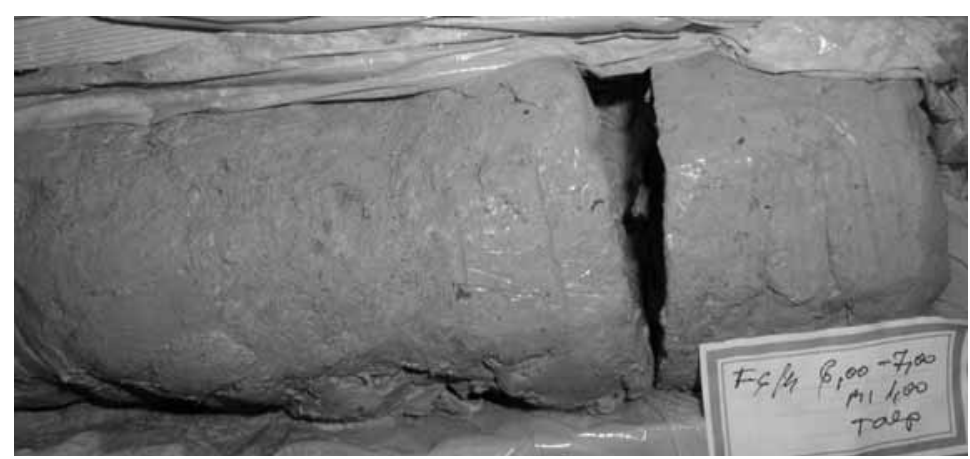

Fig. 4

Investigation of Buda Marl during construction of an underground garage (Hegyalja Street, Budapest)
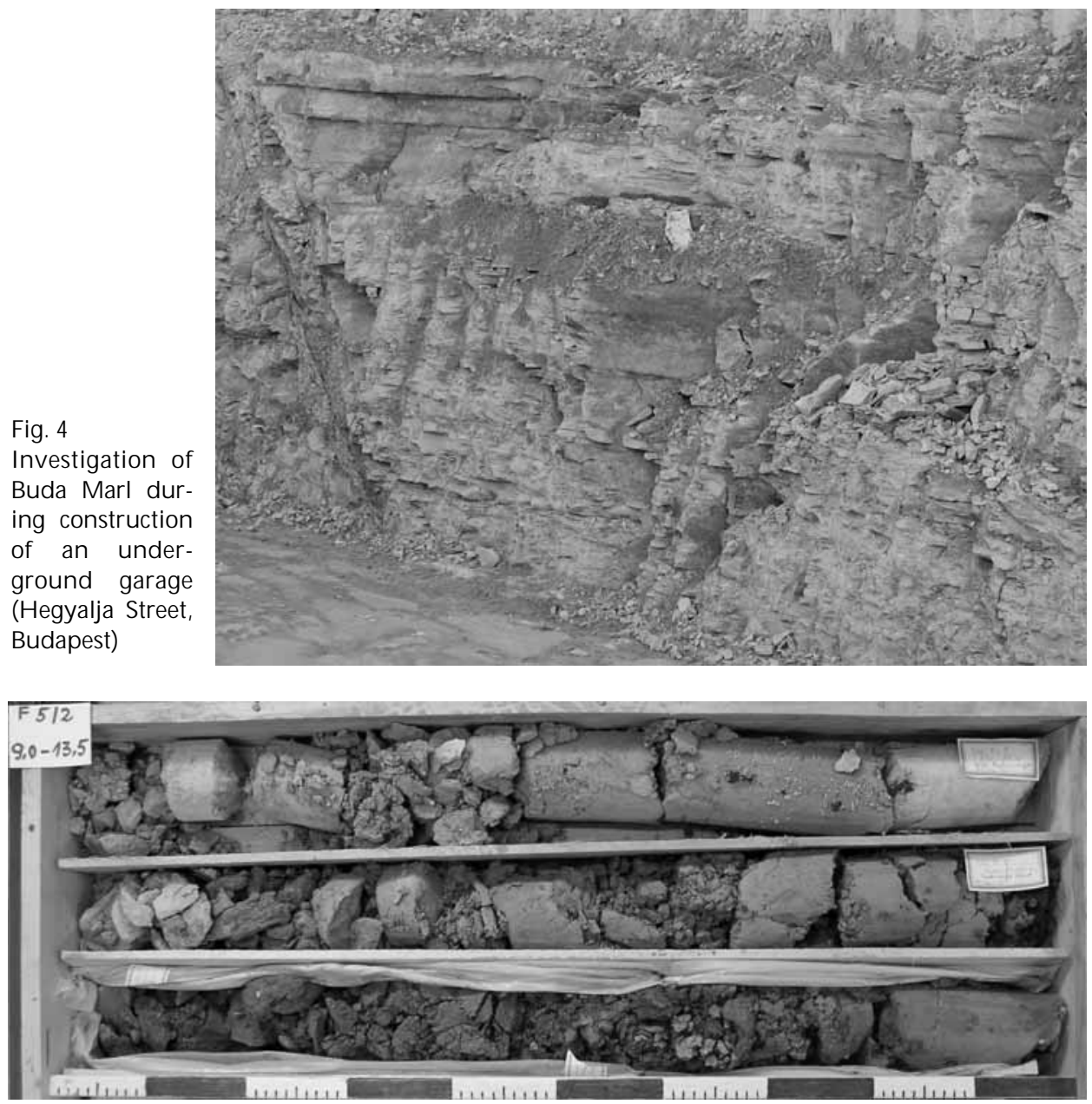

Fig. 5

Clay marl from the Castle Hill of Buda 


\section{Characterization of the rock mass of the Buda M arl}

There are several classification methods for the characterization of rock mass: the RM R method of Bienawski (1973), the Q -method (Barton et al. 1974), the RMi method of Palmström (1996) and the GSI method of Hoek (1994) and Hoek et al. (1995). In this paper the GSI (geologic strength index) was chosen for rock mass classification. This method was developed primarily for strong rocks, but its advantage is that this system is independent of the strength of the intact rock. It was modified for weak rocks by Hoek et al. (1998) and thus is useful for marl when it is neither weak rock nor soil. The determination of the GSI can be carried out using a table based upon field observations and investigation of cores. The determination of the GSI for strong rocks is presented in Fig. 6.

In this table the structure of the rock mass is presented in the rows of the table, from intact rock to disintegrated rock mass. In the columns are indicated the surface conditions (joints), from very rough to highly weathered and with clay infill. To determine the value of the GSI, application of the data in the table is not sufficient, once the geologic strength index has been created. There are several papers about the applications of the GSI for different rock masses (among others: Hoek et al. 1998, 2005; Marinos and Hoek 2001; Marinos P. et al. 2005, Marinos V. et al. 2005). These papers report practical experiences and the principal problems in determining the GSI values.

The determination of the GSI value for weak rocks is shown in Fig. 7. The table contains an additional row for laminated and sheared rocks. For these types of rock, the state of the joints can only be rated as fair; therefore the GSI value cannot be higher than 30 .

The red ellipse in Fig. 7 shows the possible GSI values for the Buda Marl. For this marl the surface conditions cannot be very good, in view of the lamination and the clay content of the rock. When the joint system is filled with water and the rock is saturated, the zone for Buda marl shifts to the right, according to the arrows in Fig. 7. Shifting decreases when the rock mass is blocky or very blocky, and increases when it is disintegrated or laminated. Usually the Buda Marl rock mass contains thin, clayey layers. These layers shift the zone showed in Fig. 7 to the right as well.

Figure 8 illustrates blocky or very blocky calcareous Buda Marl. The GSI values of this type of rock mass are between 50 and 60 (Fig. 7). In the case of disintegrated marl, shown in Fig. 9, the values of the GSI are only between 10 and 15 because the clay content of the rock mass (Fig. 7).

The value of the GSI is only the basis of a system which allows us to estimate the strength parameters of the rock mass. To estimate the strength properties of the rock mass, beside the GSI value the compressive strength value and the Hoek-Brown constant (mi) of the intact rock is also required. The compressive strength value can easily be determined for normal rocks, and the mi value by triaxial tests. According to the Hoek-Brown failure criterion (introduced by Hoek and Brown 1980) the deformation modulus, the internal friction angle and the 
cohesion of the rock mass can be estimated, knowing the GSI value. In the following section the strength properties of the Buda Marl are presented.

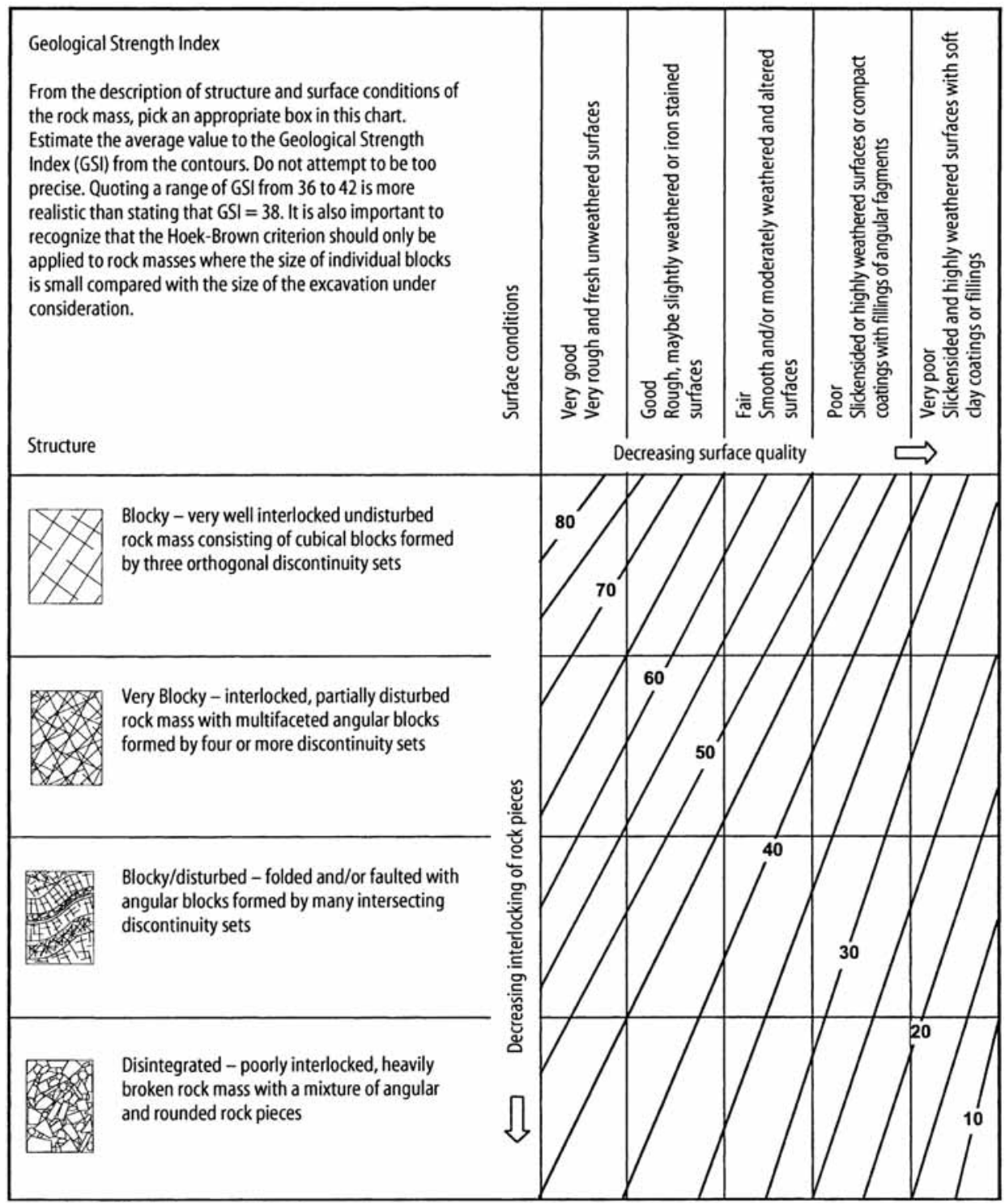

Fig. 6

Determination of the GSI for hard rocks (Hoek 1994) 


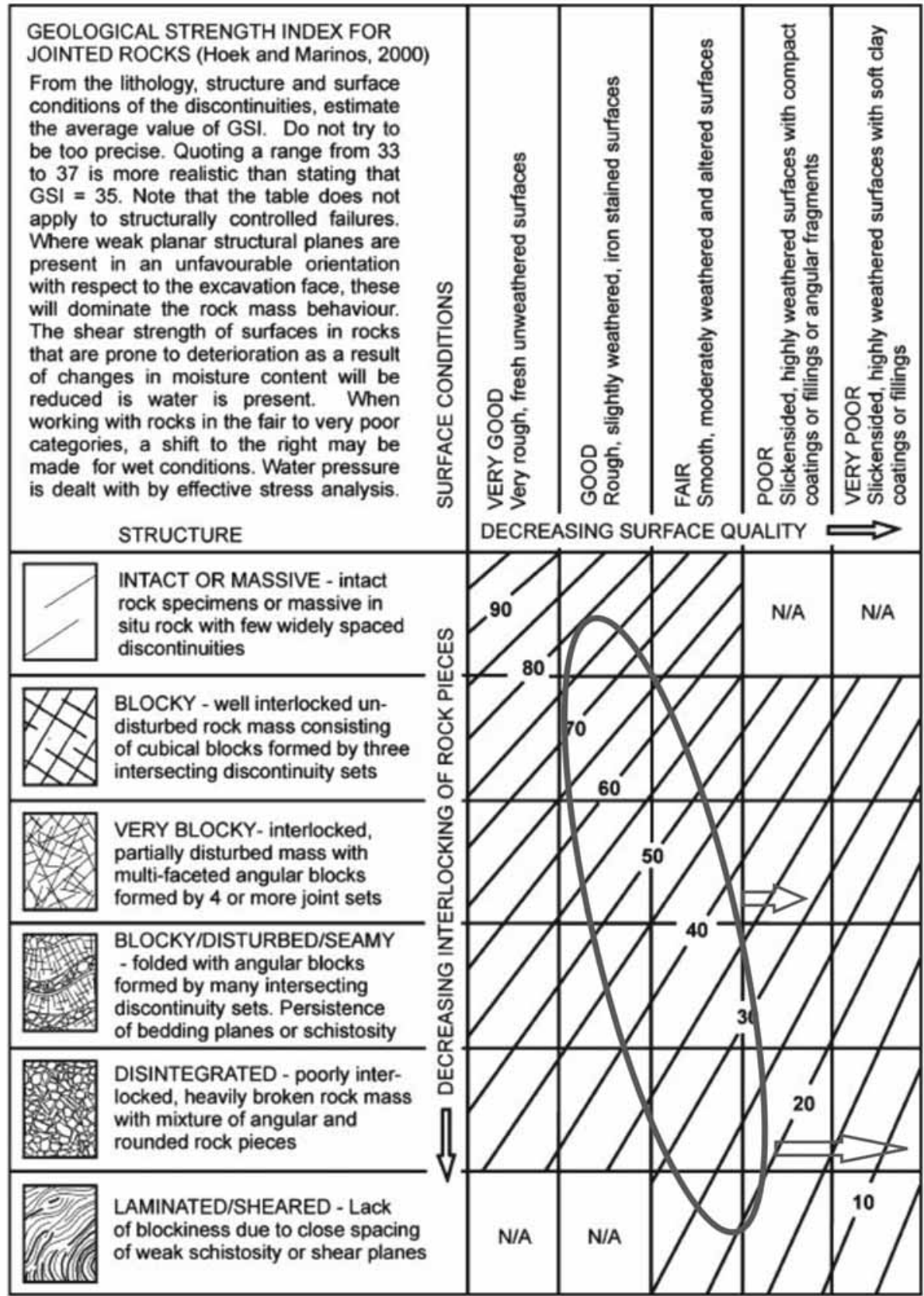

Fig. 7

Determination of the GSI including that for weak rock masses (Marinos and Hoek 2000), and the possible GSI values for the Buda Marl (red ellipse) and its changes under saturated conditions (arrows) 


\section{Characterization of the rock blocks of the B uda M arl under laboratory conditions}

Calcareous marl (Fig. 8) resembles a medium strong or strong rock, and marl behaves like a weak one. In laboratory investigations we can define the properties of the intact rock (density properties, compressive strength, tensile strength, and triaxial tests). In the laboratory of the Department of Constructional Materials and Engineering Geology, several tests were carried out on the calcareous type of Buda Marl formation (BME 1993, 1995, 1996, 2003, 2004, 2005; Harsányi 1995; Formann, 1998). In this paper the results of these investigations

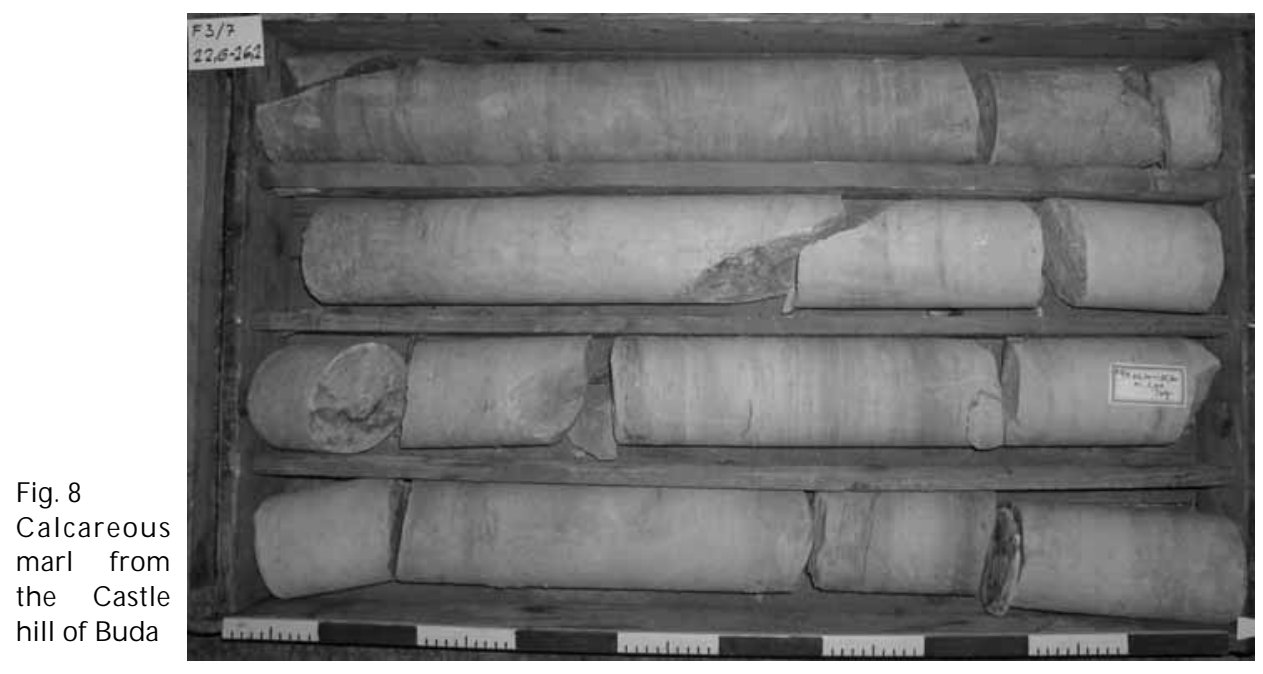

Fig. 9

Disintegrated marl from the Castle Hill of Buda

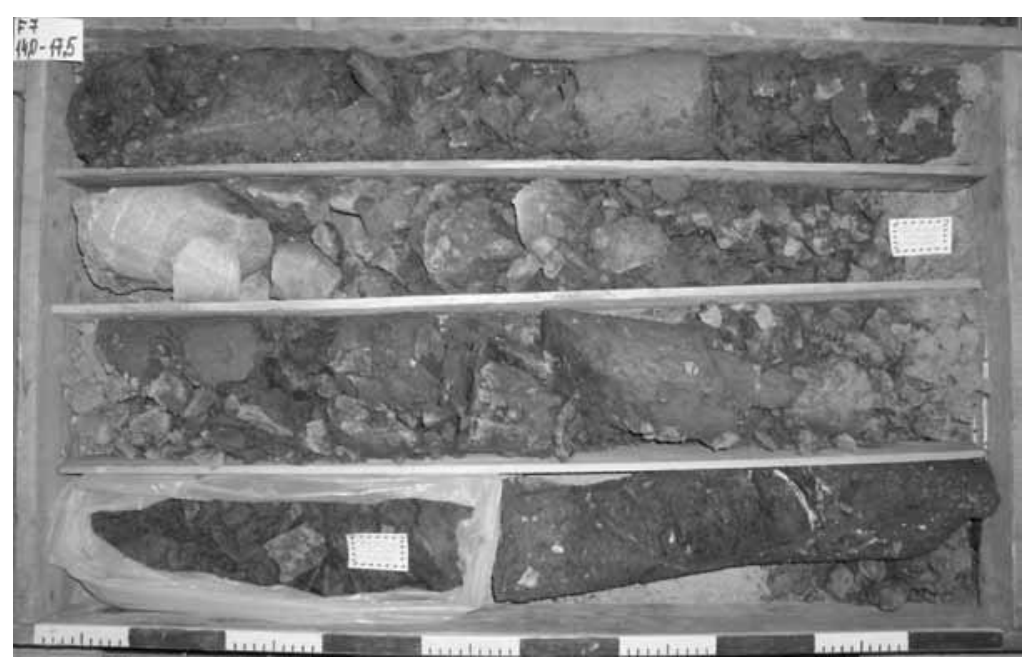


are statistically evaluated and the basic properties of the intact calcareous marl are estimated. For the statistical evaluation more than 900 data were collected; the average values of these data are presented in Table 2. The marls were analyzed in air dry as well as under saturated conditions. It is necessary to note that the samples may have partly lost their natural water content prior to saturation. To date several Hungarian rocks have been statistically analyzed (e.g. Vásárhelyi 2002; Kleb and Vásárhelyi 2003; Vásárhelyi and Gálos 2004; Vásárhelyi 2005)

A correlation relationship was sought between the different physical properties. The investigated calcareous Buda Marl was usually homogeneous, but not in the case of Young's Moduli. The spread of the Young's Moduli was more than $4000 \mathrm{MPa}$ in air-dried as well as in saturated conditions (Table 2)

Table 2

The average values of the physical properties of the calcareous type of the Buda marl

\begin{tabular}{|c|c|c|c|c|c|}
\hline \multicolumn{2}{|c|}{ Data } & \multirow{2}{*}{$\begin{array}{c}\text { Piece } \\
86 \\
\end{array}$} & \multirow{2}{*}{$\begin{array}{l}\text { Mean } \\
2468 \\
\end{array}$} & \multirow{2}{*}{$\begin{array}{c}\text { Spread } \\
83 \\
\end{array}$} & \multirow{2}{*}{$\begin{array}{r}\text { Median } \\
2487 \\
\end{array}$} \\
\hline Density & $\rho_{0}\left[\mathrm{~kg} / \mathrm{m}^{3}\right]$ & & & & \\
\hline & $\rho_{\mathrm{w}}\left[\mathrm{kg} / \mathrm{m}^{3}\right]$ & 40 & 2555 & 47 & 2558 \\
\hline \multirow{2}{*}{$\begin{array}{l}\text { Compressive } \\
\text { strength }\end{array}$} & $\sigma_{\mathrm{c} 0}[\mathrm{MPa}]$ & 90 & 43.41 & 21.77 & 38.97 \\
\hline & $\sigma_{\mathrm{cw}}[\mathrm{MPa}]$ & 43 & 30.70 & 14.74 & 30.70 \\
\hline \multirow{2}{*}{$\begin{array}{l}\text { Tensile } \\
\text { strength }\end{array}$} & $\sigma_{\mathrm{t} 0}[\mathrm{MPa}]$ & 89 & 3.81 & 2.04 & 3.68 \\
\hline & $\sigma_{\mathrm{tw}}[\mathrm{MPa}]$ & 47 & 3.16 & 1.67 & 2.87 \\
\hline \multirow{2}{*}{$\begin{array}{l}\text { Brinke } \\
\text { number }\end{array}$} & $\mathrm{B}_{0}$ & 84 & 13.32 & 6.20 & 2.87 \\
\hline & $\mathrm{B}_{\mathrm{w}}$ & 41 & 10.77 & 4.77 & 10.77 \\
\hline \multirow{2}{*}{$\begin{array}{l}\text { Shear } \\
\text { strength }\end{array}$} & $\tau_{0}[\mathrm{MPa}]$ & 53 & 5.43 & 2.43 & 5.10 \\
\hline & $\tau_{\mathrm{w}}[\mathrm{MPa}]$ & 11 & 5.22 & 1.92 & 5.22 \\
\hline \multirow{2}{*}{ Friction angle } & $\Phi_{0}\left[{ }^{\circ}\right]$ & 53 & 47.33 & 10.04 & 46.09 \\
\hline & $\Phi_{\mathrm{w}}\left[{ }^{\circ}\right]$ & 11 & 34.88 & 13.75 & 36.40 \\
\hline \multirow{2}{*}{$\begin{array}{l}\text { Young } \\
\text { module }\end{array}$} & $\mathrm{E}_{0}[\mathrm{MPa}]$ & 71 & 6872 & 4159 & 5746 \\
\hline & $\mathrm{E}_{\mathrm{w}}[\mathrm{MPa}]$ & 37 & 5849 & 4188 & 5849 \\
\hline \multirow{2}{*}{$\begin{array}{l}\text { Poisson's } \\
\text { ratio }\end{array}$} & $v_{0}$ & 61 & 0.22 & 0.10 & 0.22 \\
\hline & $v_{w}$ & 25 & 0.25 & 0.08 & 0.23 \\
\hline Porosity & $\mathrm{n}[\%]$ & 17 & 2.85 & 0.26 & 2.84 \\
\hline
\end{tabular}

The correlation between the air-dried and saturated density conditions is shown in Fig. 10. The linear regression of the correlation coefficient is $\mathrm{R}^{2}=0.821$, and the calculated equation, using the best fit method, is

$$
\rho_{w}=0.5764 \rho_{0}+1126.9
$$




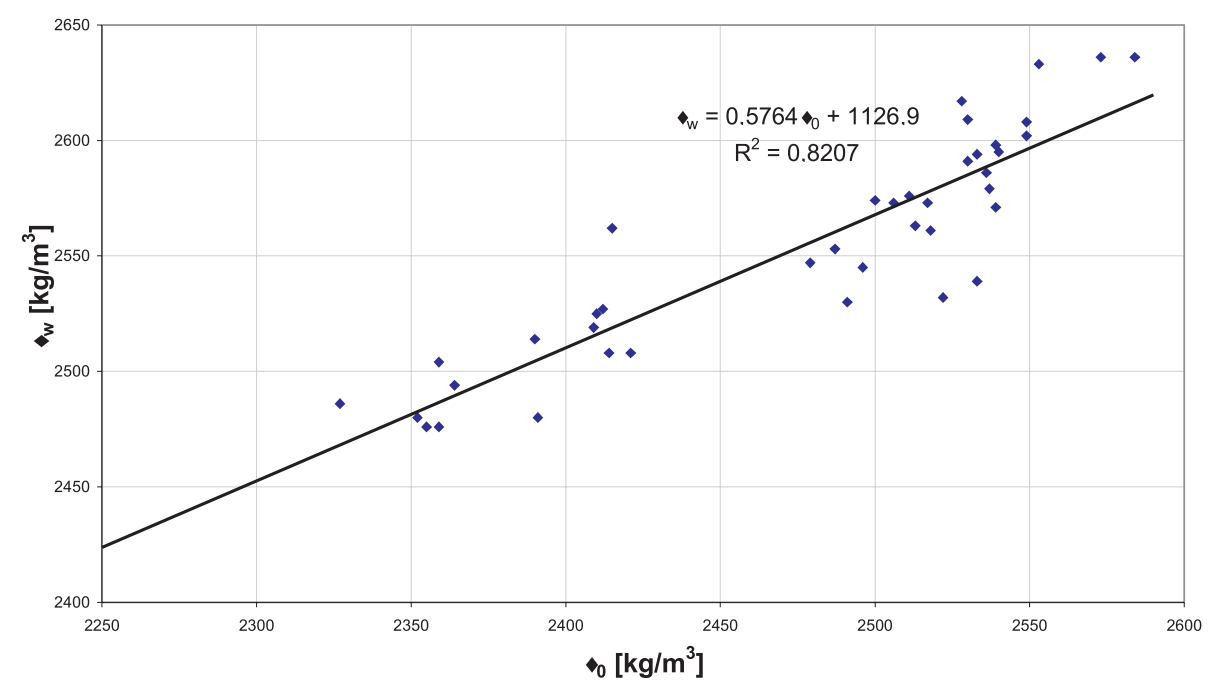

Fig. 10

Correlation between the air-dried and saturated values of density

According to this there is strong correlation between the air-dried and saturated density of the calcareous Buda Marl. If the specimens were totally homogeneous and their water absorption was the same, the points should fall on one line. The equation of this line depends on the rock constituent minerals and the effective porosity (Vásárhelyi, 2005).

Figure 11 shows the correlation between the air-dried and saturated values of compressive strength. In this case an involute function was used for best fit; the

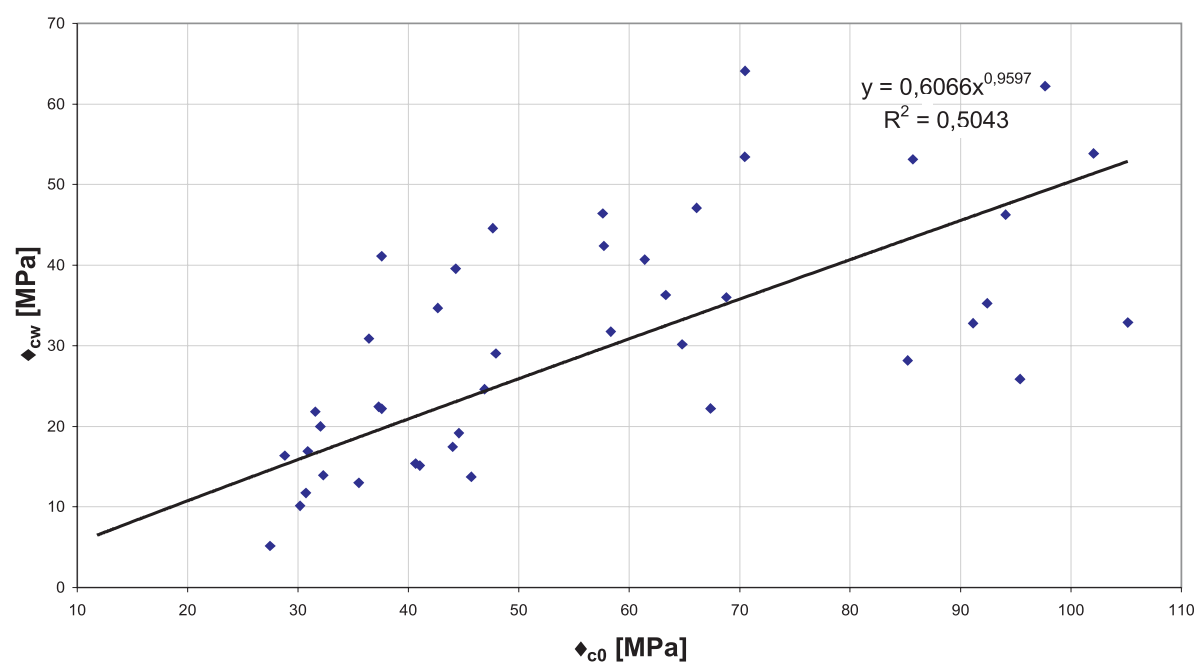

Fig. 11

Correlation between the air-dried and saturated values of compressive strength of calcareous marl 
value of the correlation coefficient was $R^{2}=0.504$. This is not an adequate correlation, as can be seen from the arrangement of the points in Fig. 11. In the case of the calcareous Buda Marl the weak correlation shows that the inherent structure of the marl has a greater impact on the compressive strength than the change of the water content: specifically, the porosity of the calcareous marl is low (Table 2); therefore its water absorption is also low.

The correlation between the air-dried and saturated values of Young's M odulus is shown in Fig. 12. Here the best approximation can also be obtained with an involute function. The correlation coefficient was $R^{2}=0.779$, and the equation of the function is

$$
E_{w}=0.0203 E_{0}^{1.3738}
$$

Calcareous marl shows a good correlation between the air-dried and saturated values of Young's Modulus.

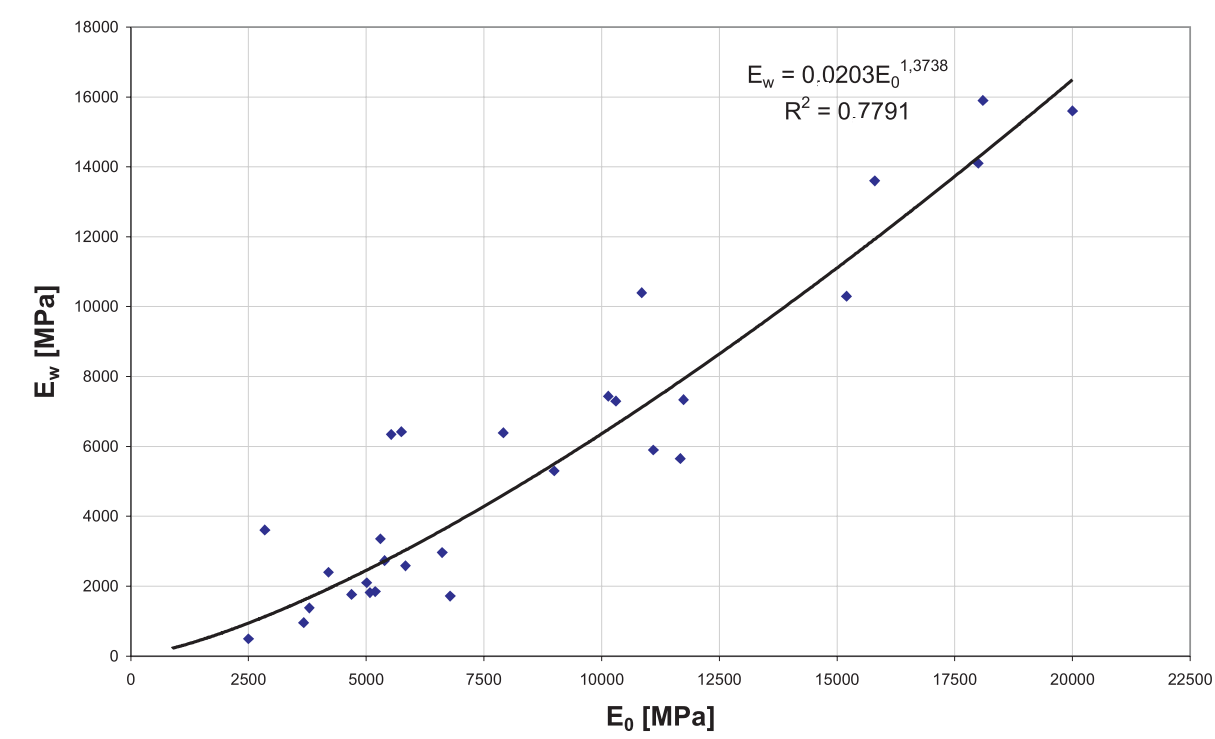

Fig. 12

Correlation between the air-dried and saturated values of Young's Modulus

Porosity and density are compared in air-dried and saturated condition as well (Fig. 13). The correlation is strong in air-dried conditions, especially when the very small range of porosity $(1.1 \%)$ is taken into consideration. The difference between the minimum and maximum values of density is only $100 \mathrm{~kg} / \mathrm{m}^{3}$.

Thus the small difference between the measured values is illustrated by a large one in the text-figure. The value of the correlation is $R^{2}=0.724$, and the equation of the line is

$$
n=0.0097 \rho_{0}+27.488
$$


Under saturated conditions the correlation is weak, with a correlation coefficient of $R^{2}=0.420$, and the equation of the line is

$$
n=0.0067 \rho_{0}+20.249
$$

The weak correlation is explained by the very small range of the values and the different degree of saturation of the samples. Since the porosity values were of insufficient number this relationship is of limited validity, and the equation could be corrected with additional porosity-density values.

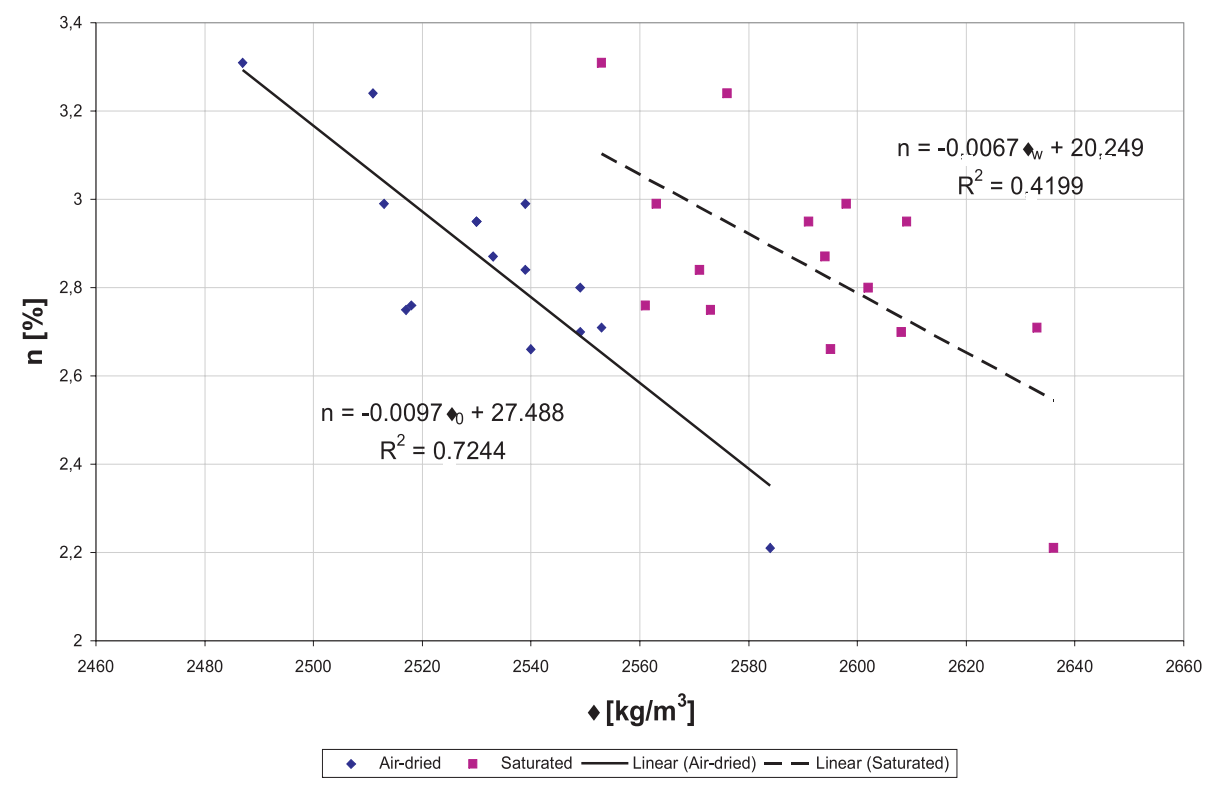

Fig. 13

Correlation between porosity and density under air-dried and saturated conditions

The correlation between Young's Modulus and density is shown in Fig. 14 for air-dried and saturated conditions. Under air-dried conditions the correlation is acceptable $\left(R^{2}=0.576\right)$, and good under saturated ones $\left(R^{2}=0.776\right)$. By using exponential approximation the equation under air-dried conditions is

$$
E_{0}=0.0029 e^{0.0058 \rho_{0}}
$$

and under saturated conditions:

$$
E_{w}=9 \times 10^{-15} e^{0.015 \rho_{p_{w}}}
$$

The correlation between compressive strength and Young's Modulus was also analyzed under air-dried and in water saturated conditions (Fig. 15). The 


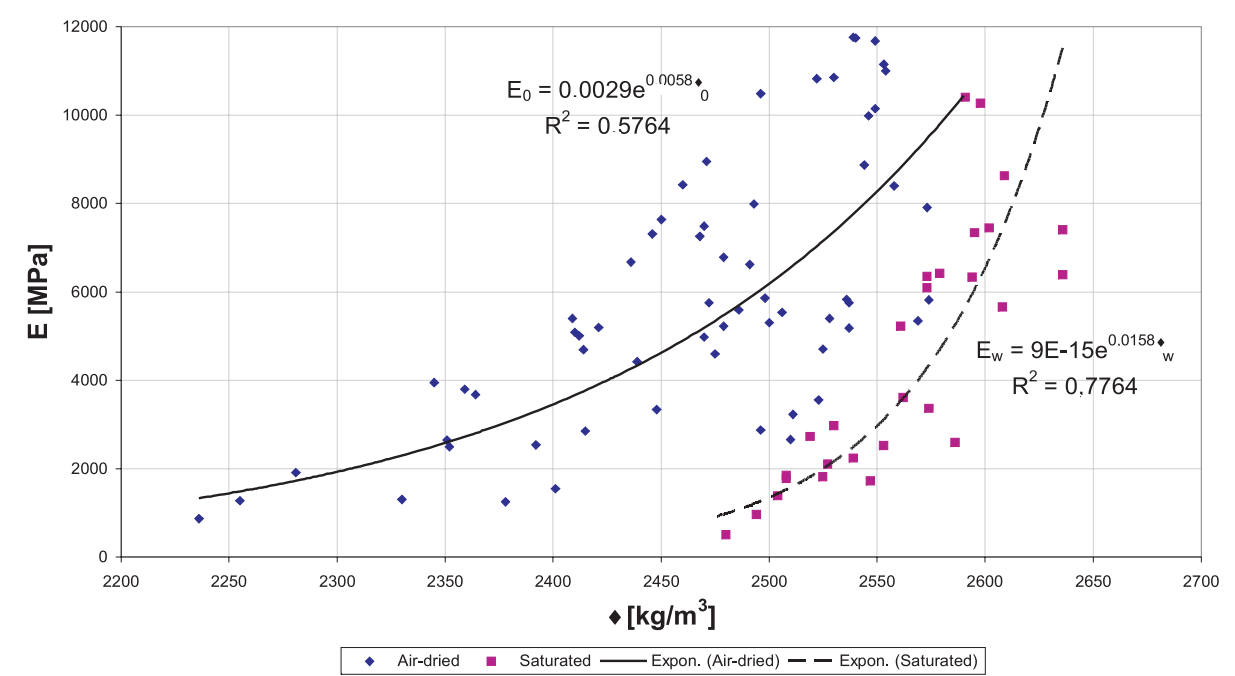

Fig. 14

Correlation between Young's Modulus and density values under air-dried and saturated conditions

correlation is good enough in both cases; for air-dried conditions the correlation coefficient is $R^{2}=0.689$ and the equation of the curve is

$$
E_{0}=36.445 \sigma_{c 0}^{1.41}
$$

For water saturated conditions the correlation coefficient is $R^{2}=0.723$ and the equation of the curve is

$$
E_{w}=73.366 \sigma_{c w}^{1.2679}
$$

There is not much difference between the two values of the correlation and the two unions of the points are almost the same. This is because the effect of water is similar in both cases. The values of Young's Modulus and of the compressive strength are lowered by an average of 50 percent through the effect of water.

These strength parameters are valid only for the intact rock. The strength parameters of the rock mass can be calculated from the parameters of the intact rock by using a rock mass classification method, for example: RMR, Q, GSI, RMi, etc.

\section{Estimation of the physical properties of the Buda $M$ arl when neither rock nor soil}

In many cases neither the rock mechanical nor the soil mechanical methods are able to determine the physical properties of the marl. It often happens that the rock is too soft and cracked to obtain a sample thereof, but at the same time too hard for plasticity analyses and the obtaining of an undisturbed sample. An example of this kind of marl can be seen in Fig. 9. In this case the strength properties of the marl can only be estimated by empirical methods. To estimate 


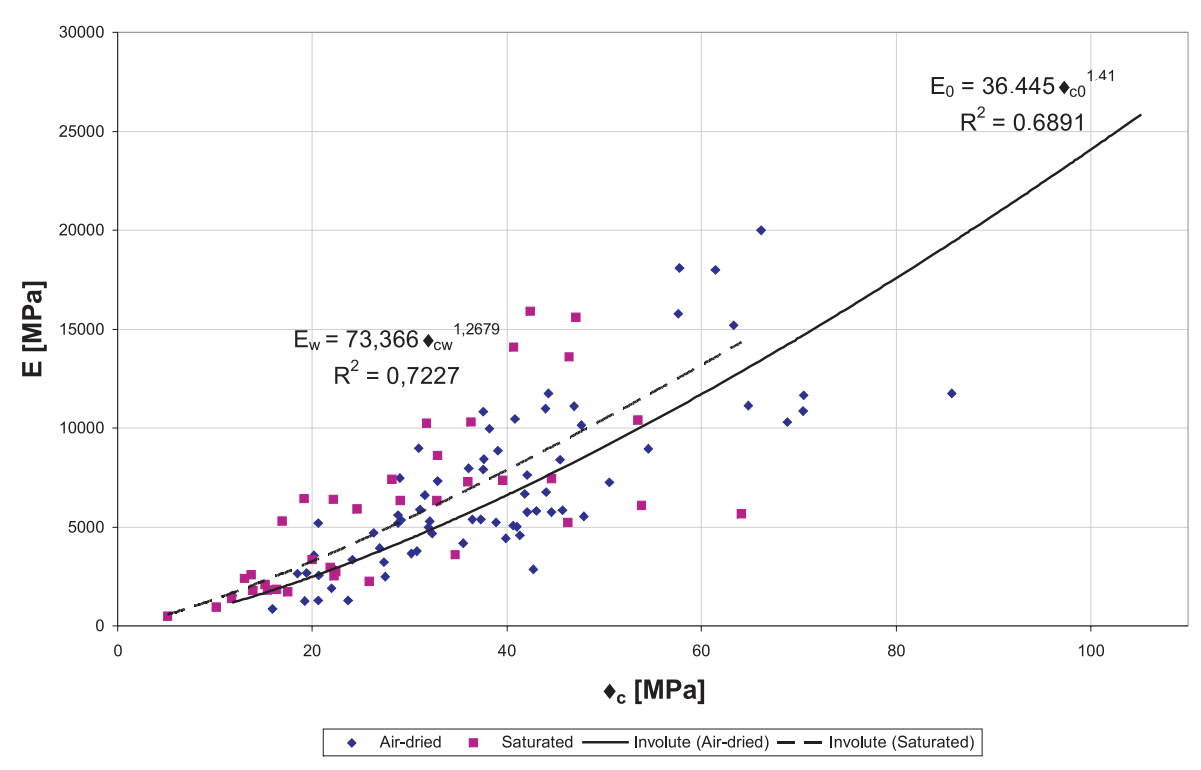

Fig. 15

Correlation between compressive strength and Young's Modulus under air-dried and saturated conditions

the strength parameters of a very weak rock mass, apart from the GSI, the compressive strength and the Hoek-Brown constant ( $\mathrm{mi}$ ) of the intact rock is also required.

Compressive strength cannot be determined when the rock is so cracked that no sample can be obtained. In this case the point load test is also capable of estimating the compressive strength of the intact rock; when the rock is clayey, however, the point load test cannot give real results. Therefore the compressive strength of the clayey rocks can be estimated according to Table 3.

\section{Estimation of strength parameters of the rock mass of the Buda M arl - the H oek-B row $n$ failure criterion}

The deformation modulus, the friction angle, and the cohesion of the rock mass can be estimated with the Hoek-Brown failure criterion when the GSI value of the rock mass, the compressive strength and the Hoek-Brown constant of the intact rock is known (Vásárhelyi 2001).

The Hoek-Brown failure criterion (Hoek and Brown 1980) is defined as

$$
\sigma_{1}=\sigma_{3}+\sigma_{c}\left(m_{b} \frac{\sigma_{3}}{\sigma_{c}}+s\right)^{a}
$$

where $\sigma_{1}$ and $\sigma_{3}$ are the minimum and maximum effective stresses in a state of failure; $\sigma_{c}$ the compressive strength of the intact rock; $m_{b}$ the Hoek-Brown Constant of the rock mass; $s$ and a constants depend on the rock mass. 
Table 3

Experimental method for estimating compressive strength (according to Hoek et al. 1998)

\begin{tabular}{|c|c|c|}
\hline $\begin{array}{l}\text { Compressive strength } \\
\text { (MPa) }\end{array}$ & Field estimate of strength & Examples \\
\hline$>250$ & $\begin{array}{l}\text { Specimen can only be chipped } \\
\text { with a geological hammer }\end{array}$ & $\begin{array}{l}\text { Fresh basalt, chert, diabase, gneiss, granite, } \\
\text { quartzite }\end{array}$ \\
\hline $100-150$ & $\begin{array}{l}\text { Specimen requires many blows } \\
\text { of a geological hammer to } \\
\text { fracture it }\end{array}$ & $\begin{array}{l}\text { Amphibolite, sandstone, basalt, gabbro, gneiss, } \\
\text { granodiorite, limestone, marble, rhyolite }\end{array}$ \\
\hline $50-100$ & $\begin{array}{l}\text { Specimen requires more than } \\
\text { one blow of a geological } \\
\text { hammer to fracture it }\end{array}$ & $\begin{array}{l}\text { Limestone, marble, phyllite, sandstone, schist, } \\
\text { shale }\end{array}$ \\
\hline $25-50$ & $\begin{array}{l}\text { Cannot be scraped or peeled } \\
\text { with a pocket a lknife, specimen } \\
\text { can be fractured with a single } \\
\text { blow from a geological hammer }\end{array}$ & Claystone, coal, concrete, schist, shale, siltstone \\
\hline $5-25$ & $\begin{array}{l}\text { Can be peeled with a pocket } \\
\text { knife with difficulty, shallow } \\
\text { indentation made by firm blow } \\
\text { with point of a geological } \\
\text { hammer }\end{array}$ & Chalk, rocksalt, potash \\
\hline $1--$ & $\begin{array}{l}\text { Crumbles under firm blows with } \\
\text { point of a geological hammer, } \\
\text { can be peeled by a pocket knife }\end{array}$ & Highly weathered or altered rock \\
\hline $0,25-1$ & Indented by thumbnail & Stiff fault gouge \\
\hline
\end{tabular}

The Hoek-Brown constant of the rock mass $\left(m_{b}\right)$ can be calculated when the Hoek-Brown constant of the intact rock $\left(m_{i}\right)$ and the GSI value are known:

$$
m_{b}=m_{i} \exp \left(\frac{G S I-100}{28}\right)
$$

The determination of the s and a constants are also based on the GSI value:

$$
s=\exp \left(\frac{G S I-100}{9}\right)
$$

$a=0.5$

In the case of weak rocks (GSI < 25), the expression is $s=0$,

$$
\mathrm{a}=0.65-\mathrm{GSI} / 200 \text {. }
$$

The Hoek-Brown constant of the intact rock can often not be tested; therefore its estimation can be carried out based on prior experience. In the case of the calcareous Buda M arl the tested value of the Hoek-Brown constant was $m_{i}=7.2$, which value can be used for marl proper as well.

With these strength parameters of the rock mass of the marl can be estimated. Based on prior experience, the Athens Schist Formation charts (Figs 16, 17) were 
established in order to estimate the strength parameters of the rock mass (Hoek et al. 1998). The Athens Schist Formation is a weak and variable rock. The Buda Marl Formation exhibits some similar properties, but the differences outweigh the similarities. Although the charts were constructed for the Athens Schist Formation, their goal was applicability elsewhere. Therefore these charts can also be used for marl with structure of blocky to disintegrated structure, but for better results they should be specially adapted for the Buda Marl. The Hoek-Brown constant $\left(m_{\mathrm{i}}\right)$ and the compressive strength $\left(\sigma_{\mathrm{c}}\right)$ of the intact rock is required to use these charts.

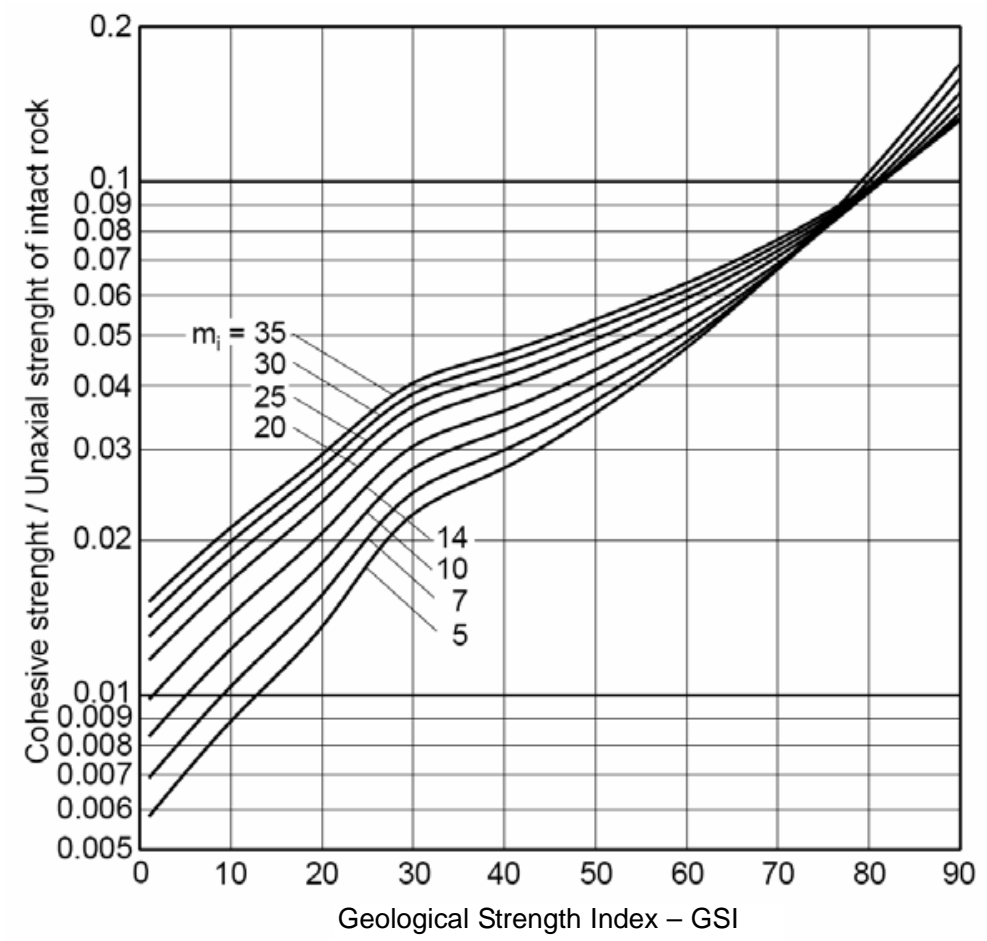

Fig. 16

Quotient of rock mass cohesion and compressive strength of the intact rock in the function of the GS value and Hoek-Brown coefficient (Hoek et al. 1998)

With this method the strength parameters are estimated empirically. Its advantage is that it provides a system for empirical methods and attempts to obtain a common experimental solution for these kinds of rocks. This method can be adopted for the rock mass of marl by experimental means. 


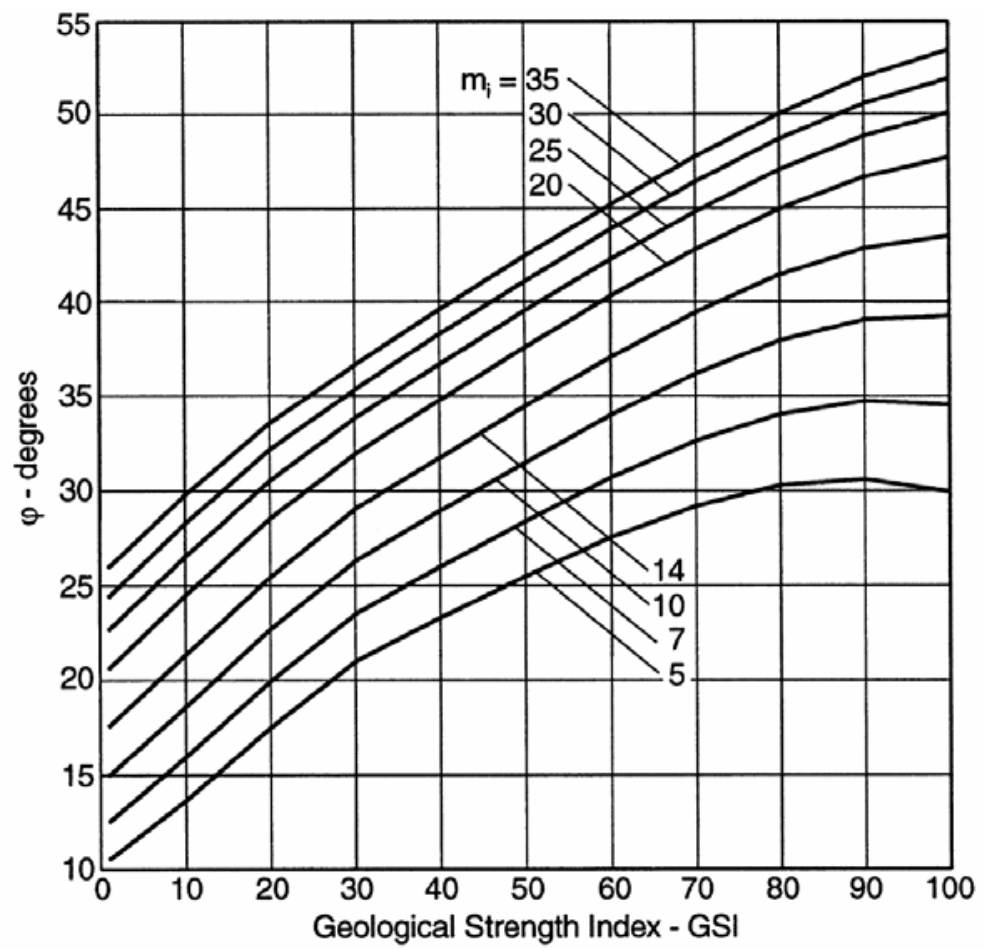

Fig. 17

Friction angle of the rock mass as a function of the GSI and Hoek-Brown coefficient (Hoek et al. 1998)

\section{Conclusions}

The properties of the Eocene Buda Marl Formation changes when it is definitely a weak rock or definitely clayey; its strength parameters can be determined with rock-mechanical or soil-mechanical methods. The adaptation of the geological strength index to the estimating of its strength parameters can be performed when the marl is so weak and cracked that no sample can be obtained from it and it is harder, that it could be investigated by soil-mechanical methods.

\section{Acknowledgements}

I am very grateful to B. Kleb and B. Vásárhelyi, who had many useful comments and suggestions; the help of Á. Török is also acknowledged. I am also grateful for the review by Stephen Fityus. 


\section{References}

Barton, N., R. Lien, J. Lunde 1974: Engineering classification of of rock masses for the design of tunnel support. -Rock Mech. Rock. Engng., 7, pp. 183-236.

Bieniawski, Z.T. 1973: Engineering classification of jointed rock masses. - Trans. S.Afr. Inst. Civ. Eng., 15, pp. 335-344.

BME 1993: Szakértõi értékelés a Budapest I. ker. Úri u. 6. számú lakóépület mélypincéjének kõzetmechanikai viszonyairól (Rock mechanical report of the cellar of the building at Budapest Úri str. 6.). - Engineering geological report (In Hungarian.)

BME 1995: A Budai Várhegy barlang- és pincerendszerével kapcsolatos veszély-elhárítási munkák megalapozását szolgáló tanulmányok készítése I. (Report of the cave and cellar system of the castle hill of Buda I). - Engineering geological report (In Hungarian.)

BME 1996: A Budai Várhegy barlang- és pincerendszerével kapcsolatos veszély-elhárítási munkák megalapozását szolgáló tanulmányok készítése II. (Report of the cave and cellar system of the castle hill of Buda II). - Engineering geological report (In Hungarian.)

BME 2003: A Budai Várkert Kioszk területén mélyített fúrások geológiai és kõzetfizikai vizsgálata (Geological and rock mechanical investigation of the core drillings in Castle Garden Kiosk of Buda). - Engineering geological report (In Hungarian.)

BME 2004: A Rác-fürdõ mellett létesítendõ mélygarázs területének mérnökgeológiai, hidrogeológiai és kõzetfizikai értékelése a lemélyített fúrások alapján (Engineering geological, hidrogeological and rock mechanical investigation of the area of the underground garage near the Rác bath). Engineering geological report (In Hungarian.)

BME 2005: A Rác fürdõ mellett létesítendõ sikló területének mérnökgeológiai és kõzetmechanikai értékelése (Engineering geological and rock mechanical investigation of the cable-railway near the Rác bath). Engineering geological report (In Hungarian.)

Formann, Z. 1998: Biztosító horgonyzás építésföldtani kérdései Budai márga kõzetösszletben (Engineering geological aspects of anchoring in the rock mass of Buda marl). - MSc Thesis (In Hungarian.)

Görög, P. 2006: A "puha" kõzet és "kemény" talaj problematikájának bemutatása a Budai márga vizsgálata alapján (The problem of weak rock and hard soil, investigation of the Buda marl). In: Török, Á., B. Vásárhelyi (Eds): Mérnökgeológia-Kõzetmechanika 2006. Mûegyetemi Kiadó, Budapest, pp. 59-72. (In Hungarian.)

Harsányi, Zs. 1995: A Budai Várhegyen létesítendõ 500 gépkocsis parkológarázs építésföldtani és építéskivitelezési vizsgálata (Engineering geological investigations of underground garage in the castle hill of Buda). - MSc Thesis (In Hungarian.)

Hoek, E. 1994: Strength of rock and rock masses. - ISRM N ews Journal, 2/2, pp. 4-16.

Hoek E., E. Brown 1980: Underground excavations in rock. - Institution of Mining and Metallurgy, London, $527 \mathrm{p}$.

Hoek, E., P.K. Kaiser, W.F. Bawden 1995: Support of underground excavations in hard rock. Rotterdam: Balkema.

Hoek, E., P. Marinos, M. Benissi 1998: Applicability of the geological strength index (GSI) classification for very weak and sheared rock masses. The case of the Athens Schist Formation. - Bull. Engng. Geol. Env., 57, pp. 151-160.

Hoek, E, P.G. Marinos, V.P. Marinos 2005: Characterisation and engineering properties of tectonically undisturbed, but lithologically varied sedimentary rock masses. - Int. J. Rock Mech. Mining Sci., 42, pp. 277-285.

Kleb, B., B. Vásárhelyi 2003: Test results and empirical formulas of rock mechanical parameters of rhiolitic tuff samples from Eger's cellars. - Acta Geol. Hung., 46/3, pp. 301-312.

Marinos, P., E. Hoek 2000: GSI : a geologically friendly tool for rock mass strength estimation. - In: Proceedings of the GeoEng2000 at the international conference on geotehnical and geological engineering, Melbourne, Technomic publishers, Lanchester, pp. 1422-1446. 
Marinos, P., E. Hoek 2000: Estimating the geotechnical properties of heterogeneous rock masses such as flysch. - Bull. Engng. Geol. Env., 60, pp. 85-92.

Marinos, P., E. Hoek, V. Marinos 2005a: Variability of the engineering properties of rock masses quantified by the geological strength index: the case of ophiolites with special emphasis on tunneling. - Bull. Engng. Geol. Env., 65, pp. 129-142

Marinos, V., P. Marinos, E. Hoek 2005b: The geological strength index: applications and limitations. Bull. Engng. Geol. Env., 64, pp. 55-65.

Paál, T. 1974: Talajfizikai jellemzõk eloszlás-vizsgálata (Distribution analyses of soil physical parameters). - Mélyépítéstudományi Szemle, 24, pp. 379-387. (In Hungarian.)

Paál, T. 1975: Regresszió analízis talajfizikai adattömegek esetén (Regression analyses of soil physical dates). - Mélyépítéstudományi Szemle, 25, pp. 22-30. (In Hungarian.)

Paál, T. 1976: A Budai agyagok mérnökgeológiai összehasonlítása matematikai statisztikai alapon (Engineering geological comparison of the clays of Buda based on Mathematical statistic methods). - Földtani Közlöny, 106, pp. 229-256. (In Hungarian.)

Palmström, A. 1996: RMi - A system for characterizing rock mass strength for use in rock engineering. - J. Rock Mech. Tunn. Techn., 1, pp. 69-108.

Vásárhelyi, B. 2001: Új eredmények a kõzet- és talajmechanikában: a Hoek-Brown törési határállapot és a Geológiai Szilárdsági Index (GSI) bemutatása (New results in the rock and soil mechanics: the Hoek-Brown failure criterion and the geological strength index (GSI). - Közúti és Mélyépítési Szemle, 51/11, pp. 424-431 (In Hungarian.)

Vásárhelyi, B. 2002: Influence of the water saturation for the strength of volcanic tuffs. - In: Dinis da Gama, C., L. Ribeire e Sousa (Eds): Workshop on volcanic rocks Madeira, pp. 89-96.

Vásárhelyi, B. 2005: Statistical analysis of the influence of water content on the strength of the Miocene limestone. - Rock Mech. Rock Engng., 38/1, pp. 69-76.

Vásárhelyi, B.; Gálos, M. (2004): How the water saturation influence the mechanical properties of the volcanic tuffs. Periodica Polytechnica - Ser. Civil Engng, 47(1): 65-72. 